\title{
Sound and Structure
}

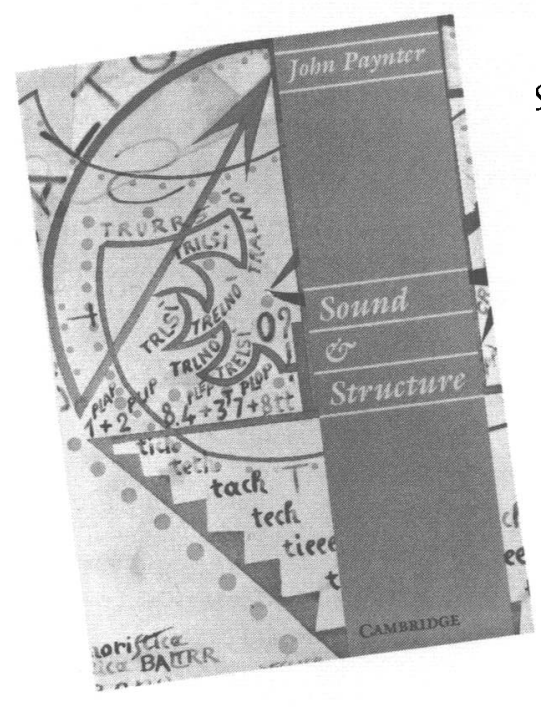

John Paynter

Using the project format of his influential work, Sound and Silence, John Paynter now addresses the composition element of music education. The detailed help he provides, particularly in matters of musical structure and the generation and development of music ideas, will be widely welcomed by music teachers.

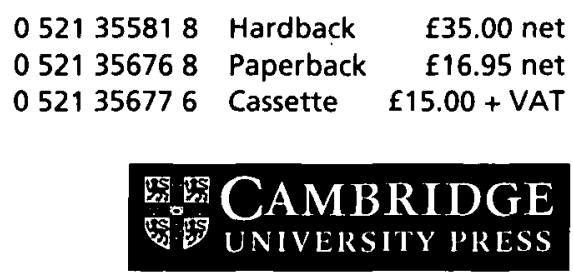

The Edinburgh Building, Cambridge CB2 2 RU 


\section{The Quarterly \\ Journal of Music Teaching and Learning \\ Manny Brand, Editor \\ Music Education Research--Reconsidered \\ Table of Contents \\ Volume II, Number 1 \\ Spring, 1992}

Editorial

By Manny Brand

Research:

Going From Incredible to Credible

By Roger H. Edwards

Research as a Means of Ascendancy in the Professoriate

By William V. May

Preparing and Nurturing Music Education Researchers

By George L. Duerksen

The State of Music Education Research

By Edward P. Asmus

Philosophy as a Method of Inquiry

By Eleanor V. Stubley

Historical Research in Music Education and Music Therapy:

A Quarter-Century of Research, Writing, and Publication

By George N. Heller

Qualitative Paradigms in Music Education Research

By Liora Bresler

Research Sessions at MENC Conferences:

1970-1990

By Steven K. Hedden

BackTalk...

Toward Increased Teacher-Researcher Communication

In Music Education Research

By Kim F. Shirey

The Quarterly Joumal of Music Teaching and Learning ISSN 1046-9133 is published four times per year by the School of Music of the University of Northern Colorado, Greeley, CO 80639. For subscritiption information, guidelines to contributors, or a sample copy, write to Managing Editor, The Quarterly Joumal of Music Teaching and Learning, University of Northern Colorado, School of Music, 123 Frasier Hall, Greeley, CO 80639. Phone (303) 351-2254 or FAX (303) 351-1923. 


\section{HANDWÖR TERBUCH DER MUSIKALISCHEN TERMIN OLOGIE}

Im Auftrag der Kommission für Musikwissenschaft der Akademie der Wissenschaften und der Literatur zu Mainz herausgegeben von Hans Heinrich Eggebrecht Schriftleitung: Christoph von Blumröder

Erscheinungsart: Einzelmonographien in Loseblattform mit alphabetischen Ordnern und Verzeichnissen; Format $21 \times 27 \mathrm{~cm}$

Erscheinungsweise: In Lieferungen zu ca. 100 Seiten (2spaltig) 1-2mal jährlich; insgesamt etwa 40 Lieferungen; DM 80,- pro Lieferung

Erschließt die Terminologie der Musik in begriffsgeschichtlichen Monographien. Als ein historisches Wörterbuch der Musik stellt es ein Arbeitsinstrument dar, das die Herkunft und Geschichte des musikalischen Fachvokabulars klärt und präzisiert und mit repräsentativen Quellenzitaten dokumentiert.

"This instalment once again reveals the organizational genius of Professor Eggebrecht and his colleagues. The lexicographical discipline exercised by the contributors is remarkable; the initial summaries of the treatment accorded to the more complex articles are particularly helpful. Sources and bibliography for each topic are dealt with in exemplary fashion."

Music and Letters

Inhalt der Lieferungen 1-19 (Lieferung 20 in Vorbereitung):

Aleatorisch, Aleatorik - Augmentatio/Augmentation - Ballade (Mittelalter) - Ballade (Neuezit) - Ballata (Trecento) - Barock - Bastarda - Blues - Bourdon - Caccia Cantus coronatus - Cantus firmus - Clausula - Clavis - Cluster - Coda - Concerto / Konzert - Conductus - Consort - Contrafactum - Contrapunctus/Kontrapunkt-Contratenor - Copula - Dauer - Diapson, diocto, octava - Diaphonia - Diminutio/Diminution -Divertimento - Divertissement-Dominante-Tonika-Subdominante-Duma/dumka Durchführen, Durchführung - Dux - comes - Elektronische Musik - Episode - Etude/ Etüde-Experimentelle Musik -Exposition -Expressionismus -Faburdon/fauxbourdon/ falso bordone-Fuga/Fuge-Gassenhauer-Gebrauchsmusik-Grundgestalt-Gruppe/ Gruppenkomposition - Handsachen, Handstücke - Hausmusik - Homophonos/aequisonus - Hoquetus - Imitatio/Nachahmung - Impressionismus - Intonatio - Intonation/intonare - intonieren - Inversio/Umkehrung - Isotonos/unisonus/unisono/Einklang - Jazz - Kadenz - Kammermusik - Kenner-Liebhaber-Dilettant - Krebsgang - Ländler Leitmotiv - Live-elektronische Musik, Live-Elektronik - Longa - brevis - Madrigale (Trecento) - Minima - Modulatio/Modulation - Modus (Rhythmuslehre) - Momentum/Moment, instans/instant, Augenblick - Monodie - Motivo/motif/Motiv - Murky - Musica falsa/musica ficta - Musica reservata - Musica sacra/heilige Musik-Musicus - cantor Musikalische Prosa - Neue Musik - Neue Sachlichkeit - Neuromantik - Notturno Nocturne - Offene Form - Oratorium - Orchester - Organistrum (11. bis 13. Jh.), Symphonia (12. bis 15. Jh.), Drehleier - Organum - Parameter - Parapter - Partitur Perfectio - Phthongos - Polyphon, polyodisch - Prolatio-Proprietas (Notationslehre) Psophos-Punctus - Punktuelle Musik - Quodlibet-Ragtime - Reihe, Zwölftonreihe Repercussio - Reprise/ripresa - Retardatio, ritardando-Rezitativ-Rhythmus/numerus - Ricercar - Romanz/romance/Romanze - Rondellus/rondeau, rota - Salonmusik Scherzo - Schlager - Semibrevis - Semiminima - Serenata/Serenade - Serielle Musik - Solus tenor - Stretto/Engführung, stretta - Subiectum/soggetto/sujet/Subjekt - Tactus -Tafelmusik - Tenor - Thematische Arbeit, motivische Arbeit - Tonsprache - Transitus - Trio-Tritonus - Unendliche Melodie - Vagierender Akkord - Vaudeville - Varietas, variatio Variation, Variante - Villanella - Virelai - Virtuose - Vollstimmig, vielstimmig, mehrstimmig - Zwölftonmusik

FRANZ STEINER VERLAG STUTTGART Postfach $101526-$ D-7000 Stuttgart 10 


\section{NOTES FOR CONTRIBUTORS}

The prime aims of the Journal are that articles should be of interest to teachers of music and show evidence of careful and critical enquiry.

Contributions and correspondence should be sent to one of the Editors:

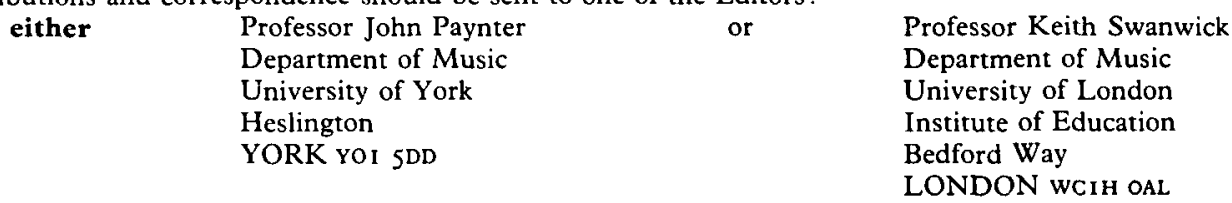

Material for review and review copy should be sent to the Review Editor:

Andrew Peggie, 4 Colchester Avenue, Manor Park, London, E12 5LE

\section{SUBMITTED \\ ARTICLES AND REVIEWS \\ Length \\ Format}

Abstract

Biographical note

Copies

Language

Stereotyping normally between 2,000 and 10,000 words.

typed in double-spacing on A4 or equivalent, one side only, with generous margins and consecutively numbered pages. Author's name should be given on a separate sheet (see Biographical note below) to facilitate the anonymous refereeing process.

about 100 words; summarizing the contents of the article; should be typed immediately below the title and above the main text. A note giving details of any acknowledgements should also be included.

of c. 75 words giving author's name, postal address, affiliation, principal publications, etc. should be submitted on a separate cover sheet.

2 copies of articles and one of reviews should be submitted and one retained for proof-reading.

writing should be clear, and jargon free; subheadings are helpful in long articles.

all forms of racial and gender stereotyping should be avoided.

It is hoped that writers will take the opportunity to present musical examples on tape. Usually a cassette tape is produced once a year, normally following the third issue of the Journal. It will have a maximum duration of ninety-two minutes and may refer to articles in each of the issues.

$\begin{array}{ll}\text { SUBMITTED } & \begin{array}{l}\text { Type } \\ \text { Quality } \\ \text { Content } \\ \text { Examples }\end{array} \\ \text { ACCEPTED } & \text { Proofs } \\ \text { ARTICLES } & \text { Copyright }\end{array}$

Offprints cassette or open-reel.

the highest possible to facilitate transfer.

in final edited form.

should not be numbered on the tape; a written numbered list of items, with timings, should be provided.

writers have the opportunity, with a given deadline, of correcting essential factual errors and any printer's errors.

writers are responsible for obtaining necessary permissions to quote copyright material; writers will be requested to assign their copyright to Cambridge University Press.

25 free offprints are supplied to writers of published articles, these shared between joint authors; further offprints may be purchased if ordered at proof stage. 


\section{QUOTATIONS AND REFERENCES}

Please identify these in the text by author and by date in brackets, e.g. '(Holmes, I981)', and list all references alphabetically by surname on a separate sheet at the end:

\begin{tabular}{|c|c|c|c|c|}
\hline format & for books state & for articles state & $\begin{array}{c}\text { for articles in } \\
\text { books state }\end{array}$ & $\begin{array}{l}\text { other notes only } \\
\text { if essential }\end{array}$ \\
\hline $\begin{array}{l}\text { type in double- } \\
\text { spacing on } \mathrm{A}_{4} \\
\text { or equivalent }\end{array}$ & $\begin{array}{l}\text { surname, initials } \\
\text { publication date } \\
\text { (in brackets) } \\
\text { title (underlined) } \\
\text { place of } \\
\text { publication } \\
\text { publisher }\end{array}$ & $\begin{array}{l}\text { surname, initials } \\
\text { publication date } \\
\text { (in brackets) } \\
\text { full title (not } \\
\text { underlined) } \\
\text { journal title } \\
\text { (underlined) } \\
\text { volume number } \\
\text { issue number } \\
\text { page number(s) }\end{array}$ & $\begin{array}{l}\text { author's name } \\
\text { publication date } \\
\quad \text { (in brackets) } \\
\text { title (in quotes) } \\
\text { 'in' } \\
\text { editor's name } \\
\text { book title } \\
\text { (underlined) } \\
\text { place of } \\
\text { publication } \\
\text { publisher }\end{array}$ & $\begin{array}{l}\text { number } \\
\text { consecutively } \\
\text { number in } \\
\text { superscript } \\
\text { list on separate } \\
\text { sheet at end }\end{array}$ \\
\hline
\end{tabular}

$\begin{array}{lll}\text { Please note: } & \text { 'Eds' } & \text { without point } \\ & \text { ' } \& \text { ' } & \text { for joint authors and in publishers' names }\end{array}$

FOR EXAMPLE Alvin, J. (I975) Music Thearapy, London: John Clare.

Boyd Willard L. (1984) 'Music: basic education'. In Donald A. Shetler (Ed), The Future of Musical Education in America, vol. 3. pp. 321-7. Rochester, NY: Eastman School of Music Press.

Holmes. M. (1981) The secondary school in contemporary western society: constraints, imperatives, and prospects. Curriculum Inquiry, 15, I, 7-36.

Howe, I. (1985) 'A plea for pluralism'. In Beatrice \& Ronald Gross (Eds), The Great School Debate, pp. 36I-2. New York: Simon \& Schuster.

Scherer, K. R. \& Ekman, P. (Eds) (1984) Approaches to Emotion. Hillsdale, NJ: Erlbaum \& Associates.

\section{IILUSTRATIONS}

\section{captions}

list and number consecurively as Figures on a separate sheet

\section{photographs}

use well-contrasted black and white prints, preferably portrait style no smaller than text width (143 mm) with glossy finish; lightly put writer's name and figure number on the back in pencil

\section{drawings and diagrams}

use Indian ink and strong paper, white card, or good quality tracing paper 


\section{BRITISH JOURNAL OF MUSIC EDUCATION \\ Volume 9 Number 2, July 1992}

\section{CONTENTS}

Biographical Notes on Contributors

Janet Hoskyns: Music Education and a European Dimension

David Collins: Creativity and special needs : a suggested framework for technology applications

Jane Southcott: The Percussion Band - Mere Noise or Music?

Michael Radford: Music, Sense and Aesthetic Education

Roland Bannister: Difficult but Sensitive: Participant Observation Reşearch in Music Education

The Impact of TVEI on Music Education:

John Winter: Music, Schools and TVEI - A Description of a Small-scale Research Project

Conference Report: Music and the World of Work

Lucy Green: The Position of Music in the Technical and Vocational Education Initiative (TVEI): a Critical Appraisal

David Ruffer: Out of Africa ... into Hastings - Reflections on African

Week at William Parker School, April 1991

\section{BOOK REVIEWS}

(c) Cambridge University Press 1992

Cambridge University Press

The Pitt Building, Trumpington Street, Cambridge CB2 IRP 40 West 2oth Street, New York, NY IooI I-42 I I, USA Io Stamford Road, Oakleigh, Victoria 3166, Australia Printed in Great Britain by the University Press, Cambridge 